심장 점액종과 관련되어 발생하는 특징적인 방추형 뇌동맥류 소견 및 문헌고찰 김중구 신지용 고근혁 최재철 오정환

제주대학교 의학전문대학원 제주대학병원 신경과

\title{
Distinctive Patterns of Intracranial Fusiform Aneurysm Associated with Cardiac Myxoma: A Case Report and Literature Review
}

\author{
Joong-Goo Kim, Jiyong Shin, Keun Hyuk Ko, Jay Chol Choi, Jung-Hwan Oh \\ Department of Neurology, Jeju National University Hospital, Jeju National University School of Medicine, Jeju, Korea
}

An intracranial aneurysm is very rare in patients with cardiac myxoma, and there is no known pathomechanism for their development. We report a case of intracranial multiple fusiform aneurysms with marked delayed contrast filling on cerebral angiography in a patient with transient ischemic attack who had undergone surgery for cardiac myxoma. The current case indicates that it is important to recognize the possibility of the occurrence of cerebral aneurysms in patients with cardiac myxoma, even if surgical treatment has been completed.

J Neurosonol Neuroimag 201\$;10(2):1\$5-1\$9

Key Words: Carney complex; Myxoma; Aneurysm; Ischemic attack, Transient
Received: November 14, 2018 Revised: December 17, 2018 Accepted: December 18, 2018

Address for correspondence: Jung-Hwan Oh

Department of Neurology, Jeju National University Hospital, Jeju National University School of Medicine, 15 Aran 13-gil, Jeju 63241, Korea

Tel: +82-64-717-1620

Fax: +82-64-717-1630

E-mail:du-mail@daum.net
심장 점액종과 연관되어 발생하는 방추형 뇌동맥류에 대한 보고가 있지만, ${ }^{1-8}$ 이러한 동맥류의 임상 양상 및 영상의학적 특징에 대하여 분석된 적은 없다. 이에, 본 저자들은 좌심방과 좌심실에서 심장 점액종을 성공적으로 절제하였던 환자에서, 22 년 뒤 일과성 허혈 발작과 특징적인 방추형 뇌동맥 동맥류 소견을 확인하였기에 보고한다. 또한, 이전 보고되었던 증례들 에 대한 문헌고찰을 통하여 심장 점액종 환자에서 발생한 방추 형 뇌동맥류의 신경 영상의학적 특징에 대하여 분석하였다.

\section{증 례}

41세 남자 환자가 내원 하루 전 발생한 일시적인 왼쪽 반신 마비로 내원하였다. 증상은 운전하던 중 갑자기 발생하였으며, 왼쪽 안면, 팔다리를 모두 포함하여 2시간 가량 지속 후 호전 되었으며, 내원시 남아있는 신경학적 이상은 없었다.

초기 피부 진찰에서 피부 진찰에서 안면부의 흑색점증을 보 였다. 과거력상 환자는 22 년 전 좌심방 점액종에 대하여 수술 받았으며, 3년 전 성병(mycoplasma genitalia)에 대하여 항 생제 치료를 받았고, 동시에 정자부족증(oligozoospermia)을
진단받았다. 사회력상 주 2회 소주 두 병을 마셨으며, 3년 전 담배는 중단하였다. 가족력 상 뇌혈관질환 또는 내분비질환은 없었다.

일과성 허혈 발작 진단 하에 뇌 자기공명영상검사(magnetic resonance imaging, MRI)를 시행하였으며, 확산강조영상에 서 급성 뇌경색 소견은 없었고, $\mathrm{T} 1, \mathrm{~T} 2$ 강조영상 및 액체 감쇠 역전회복(fluid attenuated inversion recovery, FLAIR) 영 상에서 양측 소뇌와 좌측 시상에서 다발성 열공성 허혈성 병 변이 있었다. 또한 FLAIR 영상에서 우측 아래전두이랑(inferior frontal gyrus) 주변으로 고신호강도가 보였으며, T1 강 조영상에서도 우측 전두엽 피질에 고신호강도가 있었다(Fig. 1). $\mathrm{MR}$ 혈관조영술에서 우측 전두엽 피질에 확장된 혈관 구 조가 확인되어 시행한, 디지털 감산 혈관조영술(digital subtraction angiography, DSA)에서 우측 중대뇌동맥(middle cerebral artery) 원위부 혈관이 갈라져 나뉘는 부위에 방추형 모양의 뇌동맥류가 관찰되었다(Fig. $1 \mathrm{~A}-\mathrm{C}$ ). 방추형 뇌동맥류 가 위치한 혈관의 조영은 다른 혈관에 비하여 현저히 지연되었 으나 피질 동맥의 폐색은 관찰되지 않았다(Fig. 1D).

초기 진찰시 환자의 이마와 광대가 돌출되고, 코와 입술이 두꺼워져 있었으며, 손과 손가락이 두껍고 커져 있어, 말단 


\section{JNN}

Kim JG, et al. Myxomatous Fusiform Aneurysm
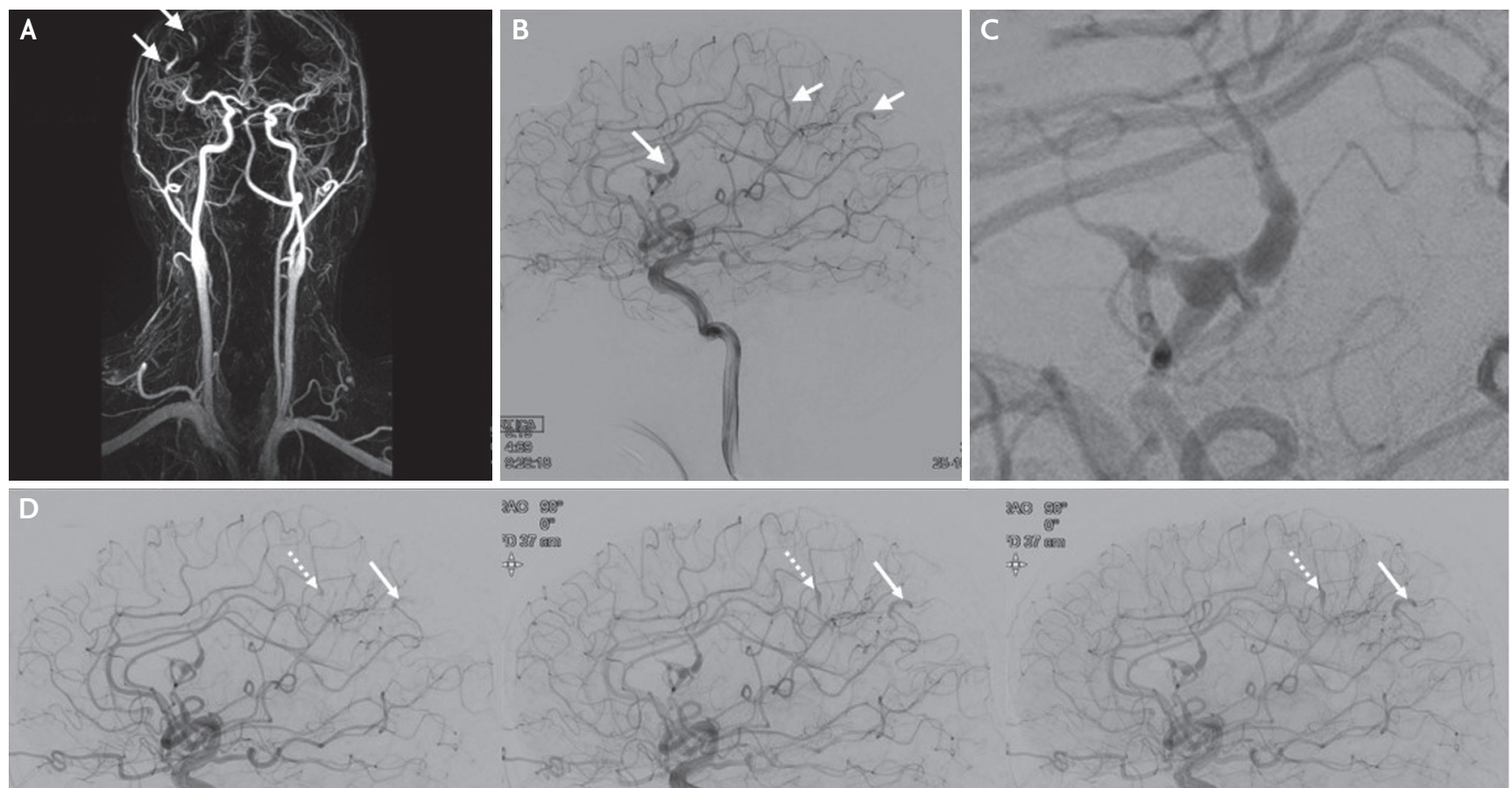

अ⿻

$\operatorname{xag} 9 g^{\circ}$

A

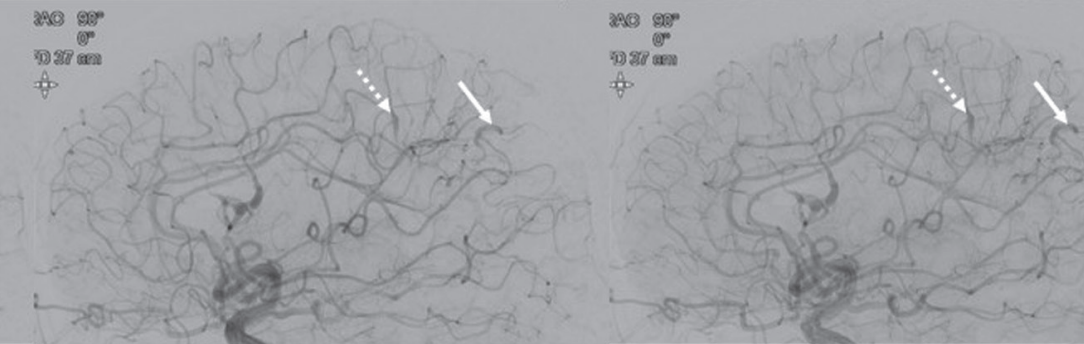

का)

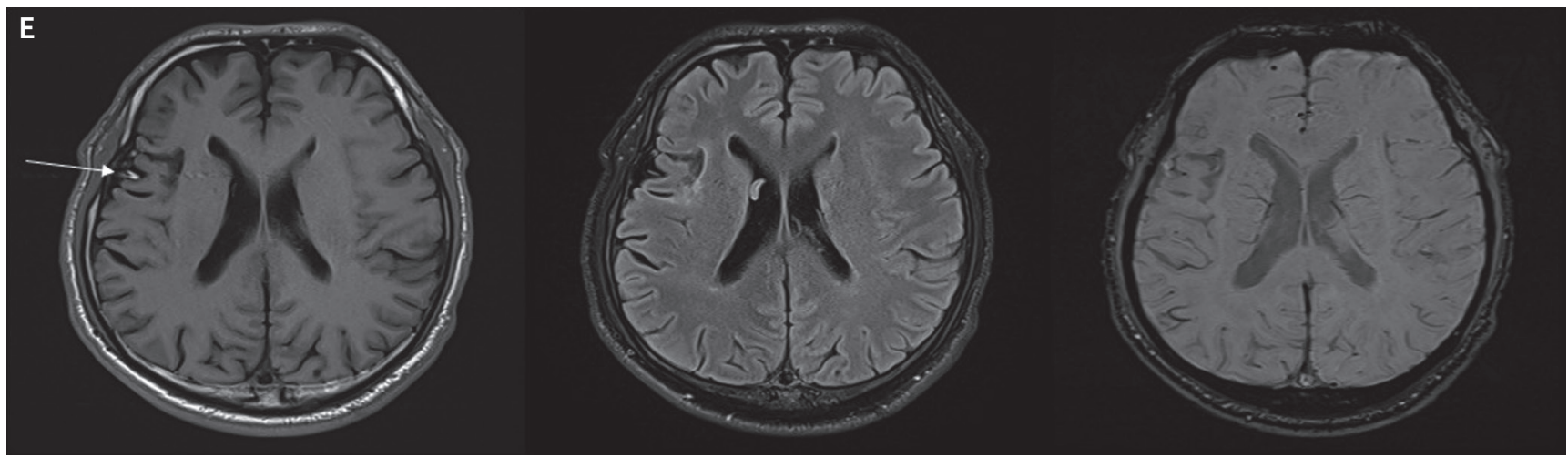

Fig. 1. (A) MR angiogram reveals the ectatic change of a cortical aneurysm (white arrows). (B) Lateral view of the right internal carotid angiogram shows fusiform aneurysms on the middle and anterior cerebral arteries (white arrows). (C) Delayed filling of the dysplastic fusiform aneurysm at the cortical branches bifurcation of the right middle cerebral artery. (D) The dysplastic cortical fusiform aneurysm located in the left middle cerebral artery does not flow in the initial arterial phase, but the filling of the contrast is delayed into the ectatic lumen sequentially (dot arrows and white arrows). (E) Axial T1-weighted spin-echo MR imaging demonstrates dilated peripheral middle cerebral artery branches suggestive of fusiform dilatations (white arrow).

비대증을 의심하여 호르몬검사를 진행하였다. 검사 결과 삼 요드티로닌(triiodothyronine, T3) $0.59 \mathrm{ng} / \mathrm{mL}$ (정상 범 위: $0.80-2.00$ ), 유리 갑상샘 호르몬 $1.31 \mathrm{ng} / \mathrm{dL}$ (정상 범 위: 0.93-1.70), 갑상샘자극호르몬 $0.86 \mathrm{uIU} / \mathrm{L}$ (정상 범위: $0.27-4.20$ ), 성장호르몬 $7.62 \mathrm{ng} / \mathrm{mL}$ (정상 범위: <1.98), 인슐린 유사성장인자(insulin like growth factor)-I 588.17 $\mathrm{ng} / \mathrm{mL}$ (정상 범위: 124-290), 코르티솔 $13.62 \mathrm{ng} / \mathrm{dL}$ (정상 범위: $6.2-19.4$ ), 프로락틴 $14.6 \mathrm{ng} / \mathrm{mL}$ (정상 범위: 4.0415.2 ), 부신피질자극호르몬 $34.12 \mathrm{pg} / \mathrm{mL}$ (정상 범위: $7.2-$ 63.3)였다. 항갑상샘항체검사 결과는 항갑상샘 자극호르몬수 용체 항체 $0.3 \mathrm{IU} / \mathrm{L}$ (정상 범위: 0-1.75), 항갑상샘 글로불린
항체 $7.61 \mathrm{IU} / \mathrm{mL}$ (정상 범위: 0-34)였다. 포도당 부하(Diasol-S $75 \mathrm{~g}$ )에 의한 성장호르몬억제검사에서 성장호르몬은 120 분까지 억제되지 않았고, 복합 뇌하수체자극검사에서 갑상 샘 자극호르몬은 증가하지 않았다. 특징적인 피부 소견 및 성장 호르몬 과다분비에 의한 말단비대증과 과거 심장 점액종을 진 단받았기 때문에 Carney complex로 진단기준에 부합하였다. 심장 초음파에서 심장 점액종의 재발은 관찰되지 않았다. 아스 피린 및 스타틴 복용을 시작한 이후, 일과성 허혈성 발작 증상 의 재발은 없었고, 방추형 동맥류에 대해서는 수술적 치료 없이 경과 관찰하기로 하였다. 말단비대증에 대해서는 나비뼈경유수 술(transsphenoidal surgery)로 뇌하수체를 절제하였다. 


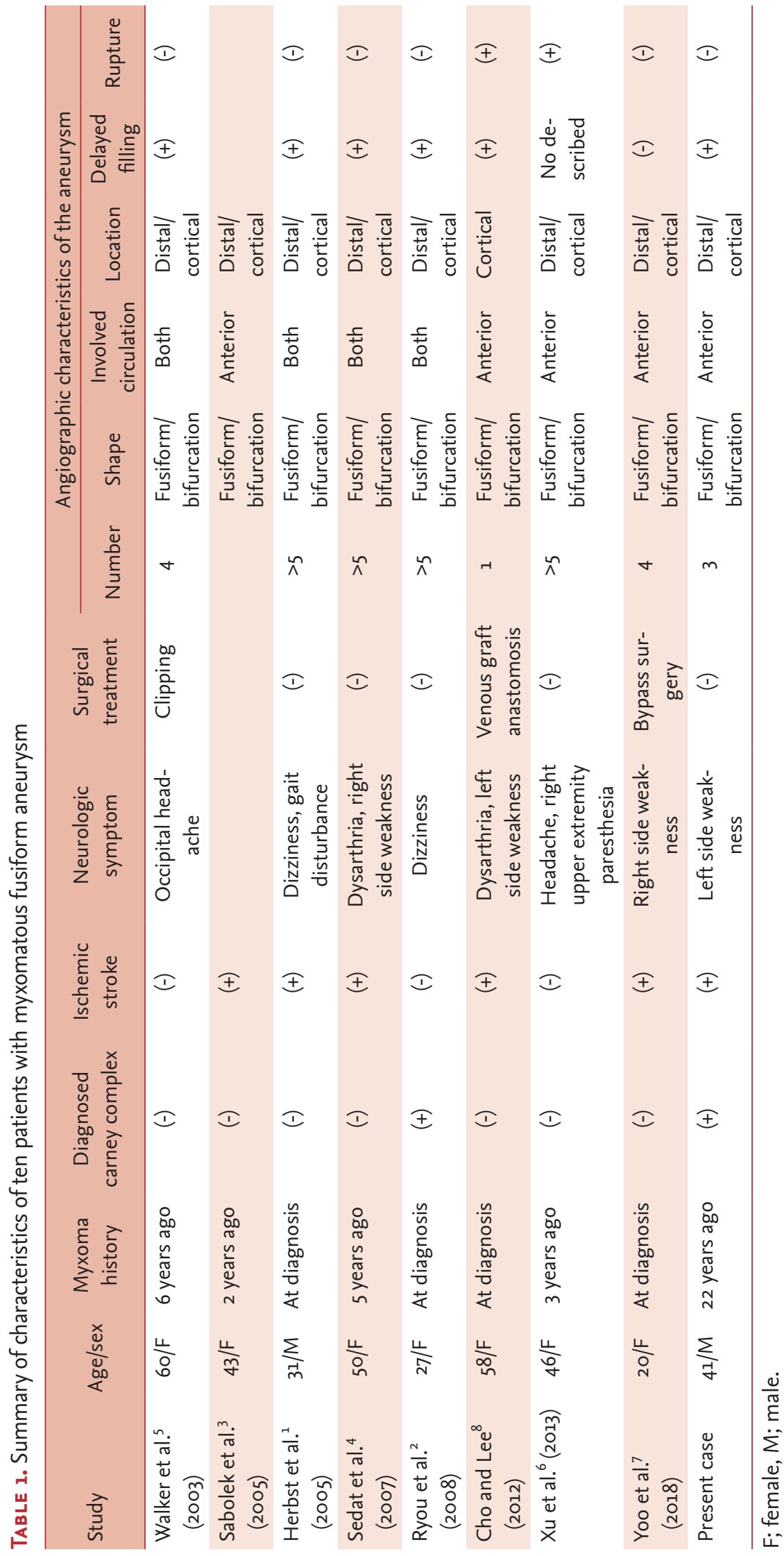




\section{고 찰}

심장 점액종과 연관되어 발생하는 방추형 뇌동맥류는 드물 지만, 현재까지 약 50 예 정도가 보고되어 왔다. 이 중에서 뇌 $\mathrm{MRI}$ 및 $\mathrm{DSA}$ 의 영상 자료가 포함된 8개의 증례를 본 환자의 증례와 함께 정리하였다(Table 1).

Carney complex는 매우 드문 내분비 종양 증후군으로서 피부와 점막 표면의 독특한 색소 병변, 심장 또는 비심장 점액 종양, 다발성 내분비 종양을 특징으로 한다. Carney complex 는 protein kinase A type I-alpha regulatory subunit gene (PRKAR1A)의 돌연변이와 가장 관련이 있으며 상염색 체 우성으로 유전된다. 그러나 약 $25 \%$ 의 경우 가족력 없이, de novo하게 발생하는 것으로 알려져 있다. 본 증례에서 진단 은 2010년 Almeida와 Stratakis ${ }^{9}$ 가 제시한 기준에서 심장 점 액종 및 성장호르몬을 생성하는 선종으로 인한 말단 비대증을 만족하여 진단되었다.

심장 점액종과 연관되어 발생하는 뇌동맥류는 대부분 방추 형 모양을 보이며, 아주 드물게는 소낭성(saccular) 형태로 나 타난다. ${ }^{10}$ 대부분 대뇌 혈관의 근위부보다 원위부에서 발견되 며, 일반적인 방추형 뇌동맥류와는 다른 특징적인 형태를 보인 다. 특징적으로, $\mathrm{DSA}$ 에서 뇌혈관 원위부의 분지 부위에서 ' $\mathrm{Y}$ shape'을 보이며(Fig. 1A-C), 동맥류 전후로 혈류가 현저히 느려져, 모세혈관기(capillary phase)에서도 조영제가 남아 있는 것을 볼 수 있다(Fig, 1D). 이는 T1과 FLAIR 영상에서도 피질의 동맥류 모양이 관찰되는 것을 고려할 때(Fig. $1 \mathrm{E})$, 혈 류지연을 시사하는 소견이라 할 수 있다. 이전 보고에서도 심 장 점액종과 연관된 방추형 동맥류 원위부로 혈류 저하 또는 심지어 원위부 혈관의 폐색을 보이는 증례들이 보고된 바 있 다. ${ }^{1,4,5}$

심장 점액종과 연관되어 발생한 방추형 뇌동맥류는 혈관 박 리, 동맥경화증 또는 결합조직질환(connetive tissue disease) 과 연관되어 보고되는 방추형 뇌동맥류와는 발생기전이 다를 것으로 추정된다. 방추형 뇌동맥류는 1) 내 탄성판(internal elastic lamina)의 손상, 2) 비대된 혈관 내막(intima) 내부 로 혈관신생(neoangiogenesis), 3) 혈관 벽 내의 출혈 및 혈 전 생성, 4) 혈전 내부에 새롭게 형성된 혈관에 의한 반복된 혈 관벽내 출혈로 발생한다. ${ }^{10}$ 그러나 심장 점액종과 연관되어 발 생한 방추형 뇌동맥류 발생기전은 아직 잘 알려지지 않았지만, 1) 점액종 자체의 색전 이후 뇌혈관 벽이 손상, 2) 점액종이 뇌 혈관으로 전이되어 혈관 내에서 종양세포의 성장, 3) 전이된 세포에 의해 혈관 벽의 혈관 맥관(vasa vasorum)이 침범됨에 따라 정상 혈관 벽의 구조가 파괴되어 발생한다는 가설들이 제 시되고 있다. ${ }^{3,4}$

일반적인 뇌동맥류 치료는 방추형 뇌동맥류의 경우, 중재 적 치료와 수술적 치료가 제시된다. 중재적 치료는 방추형 동 맥류 안쪽으로 스텐트 삽입술과 코일 색전술을 병행하거나 flow-diverter를 사용하며, 수술적 치료로는 외경동맥 문합술 또는 클립을 사용한 혈관 성형술 등이 보고되었다. ${ }^{10}$ 그러나 아직 심장 점액종과 연관된 방추형 동맥류의 치료 방침은 정립 되지 않았다. 그 이유는 뇌동맥류 파열에 대한 예측이 어려울 뿐만 아니라, 발생 부위가 특징적으로 ' $\mathrm{Y}$ shape'으로 갈라져나 가는 원위부 분지에 발생하기 때문에 중재적, 수술적 치료 모 두 어려운 경우가 대부분이기 때문이다. ${ }^{3}$

본 증례에서는 비록, 뇌 MRI 영상에서 양측 소뇌와 좌측 시 상의 다발성 열공성 허혈성 변화를 보인 점을 고려할 때, 일시 적인 왼쪽 상하지 마비는 소혈관질환에 의한 일과성 허혈성 발 작을 배제할 수 없다. 그러나 DSA에서 우측 중대뇌동맥의 원 위부의 분지의 현저한 혈류 속도 감소는 일과성 허혈 발작의 원인일 수 있다.

저자들은 본 증례를 포함하여 총 9 명의 심장 점액종과 연관 된 방추형 뇌동맥류 환자들의 신경영상 소견 및 일반적인 방추 형 뇌동맥류와의 차이에 대하여 정리하였다. 심장 점액종에 대 한 수술적 치료가 완료되었다 하더라도, 정기적인 신경영상검 사가 필요하며, 특징적인 형태의 방추형 뇌동맥류의 발생 가능 성에 대하여 인지하는 것이 중요하다. ${ }^{2}$ 또한, 신경학적 이상으 로 시행한 뇌 영상에서, 원위부 분지에 방추형 뇌동맥류가 관 찰되며, 혈관 조영술에서 혈류의 지연 또는 폐색이 관찰되는 특징적인 형태가 관찰될 경우, 심장 점액종에 대한 검사가 필 요하며, 나아가서 Carney complex가 동반할 수 있음을 주지 해야 한다. ${ }^{2}$

\section{Acknowledgments}

This work is attributed to and was solely supported by the Department of Neurology, Jeju National University Hospital, Jeju, Korea.

\section{Conflicts of Interest}

No potential conflict of interest relevant to this article was reported.

\section{REFERENCES}

1. Herbst M, Wattjes MP, Urbach H, Inhetvin-Hutter C, Becker D, Klockgether T, et al. Cerebral embolism from left atrial myxoma leading to cerebral and retinal aneurysms: a case report. AJNR Am J Neuroradiol. 2005;26:666-669.

2. Ryou KS, Lee SH, Park SH, Park J, Hwang SK, Hamm IS. Multiple fusiform myxomatous cerebral aneurysms in a patient with Carney complex. J Neurosurg. 2008;109:318-320.

3. Sabolek M, Bachus-Banaschak K, Bachus R, Arnold G, Storch A. Multiple cerebral aneurysms as delayed compli- 
cation of left cardiac myxoma: a case report and review. Acta Neurol Scand. 2005;111:345-350.

4. Sedat J, Chau Y, Dunac A, Gomez N, Suissa L, Mahagne MH. Multiple cerebral aneurysms caused by cardiac myxoma. A case report and present state of knowledge. Interv Neuroradiol. 2007;13:179-184.

5. Walker MT, Kilani RK, Toye LR, Bird CR. Central and peripheral fusiform aneurysms six years after left atrial myxoma resection. J Neurol Neurosurg Psychiatry. 2003;74:281-282.

6. Xu Q, Zhang X, Wu P, Wang M, Zhou Y, Feng Y. Multiple intracranial aneurysms followed left atrial myxoma: case report and literature review. J Thorac Dis. 2013;5:E227-E231.

7. Yoo HJ, Chung J, Ahn JS. Cerebral myxomatous aneurysm treated by M2-M2 bypass: a case report. Nerve. 2018;4:120122.

8. Cho YN, Lee KY. Concurrent events of embolic cerebral infarction and cerebral aneurysm with hemorrhage in a patient with cardiac myxoma. J Korean Neurol Assoc. 2012;30:358-360.

9. Almeida MQ, Stratakis CA. Carney complex and other conditions associated with micronodular adrenal hyperplasias. Best Pract Res Clin Endocrinol Metab. 2010;24:907-914.

10. Park SH, Yim MB, Lee CY, Kim E, Son EI. Intracranial fusiform aneurysms: it's pathogenesis, clinical characteristics and managements. J Korean Neurosurg Soc. 2008;44:116-123. 